Chirurgia (2018) 113: 634-643

No. 5, September - October

Copyright@ Celsius

http://dx.doi.org/10.21614/chirurgia.113.5.634

\title{
Surgical Management of Diabetic Neuropathy Foot Complications
}

\author{
Dragoș Eugen Georgescu, ${ }^{1,2}$, Petronel Mustațea ${ }^{1,2}$, Octavian Mihalache ${ }^{1,2}$, Florin Bobircă ${ }^{1,2}$, Alexandra Agache ${ }^{1,2}$, \\ Teodor Florin Georgescu ${ }^{2}$, Ovidiu Chiriac', Vlad Marin', Horia Doran ${ }^{1,2}$, Traian Pătrașcu ${ }^{1,2}$
}

1"I. Juvara" Surgical Department, "Dr. I. Cantacuzino" Clinical Hospital, Bucharest

2"Carol Davila" University of Medicine and Pharmacy, Bucharest

Corresponding author:

Assistant Professor Florin Teodor Bobircă General Surgery

"Dr. I. Cantacuzino" Clinical Hospital

5-7 Ion Movila str., district 2, Bucharest

Romania

E-mail: dr.bobirca@gmail.com

\section{Rezumat}

Managementul chirurgical al complicatiilor piciorului diabetic neuropat

Introducere: Complicațile piciorului diabetic sunt rezultatul asocierii dintre boala vasculară periferică, neuropatie şi un proces de vindecare precar. Neuropatia periferică observată la diabetici afectează toate componentele sistemului nervos, senzitiv, motor şi autonom, fiecare contribuind la apariția ulcerațiilor piciorului. Pe fondul neuropatiei apar modificări musculo scheletale şi ale arhitecturii piciorului conducând la deformări severe. Manifestarea clinică a acestor complicații variază de la leziuni simple până la entități complexe amenințătoare de pierderea membrului pelvin sau chiar de viață $(1,2)$.

Material şi Metodă: În Clinica de Chirurgie a Spitalului Clinic Dr. I. Cantacuzino din Bucureşti sunt internați şi trataţi anual un număr semnificativ de pacienți cu leziuni de tip picior diabetic, $40 \%$ având manifestări clinice de neuropatie diabetică. În 2017 dintr-un total de 448 de pacienți, internați pentru complicații ale diabetului zaharat, am efectuat o analiză retrospectivă a 150 pacienți consecutivi care au suferit intervenții chirurgicale pentru leziuni de picior diabetic cu predominanța neuropatiei.

Rezultate: Pacienții analizați au avut o evoluție postoperatorie favorabilă, beneficiind de suport circulator. Rezecția de raze a fost interventia chirurgicală preferată. Amputația majoră a fost efectuată la $10 \%$ din pacienți, cu gangrene extensive şi sepsis, amputația de gambă fiind preferată în toate situațiile.

Concluzii: Managementul chirurgical al acestor pacienți este delicat, 
de multe ori fiind necesar un abord multidisciplinar. $\mathrm{O}$ atitudine teraputică bine condusă poate face diferența între prezervarea sau pierderea membrului pelvin.

Cuvinte cheie: neuropatie, diabet zaharat, ulcerație, Charcot

\begin{abstract}
Background: Diabetic foot complications result from the association between peripheral vascular disease, neuropathy and a precarious healing process. Peripheral neuropathy observed in diabetics affects all components of the nervous system, contributing to the occurrence of leg ulcers, musculoskeletal changes, resulting in severe deformities. The clinical manifestation of these complications ranges from simple lesions to complex entities threatening the loss of pelvic limb or even life $(1,2)$. Methods: In our surgery department, a significant number of patients with diabetic foot lesions are hospitalized and treated annually, 40\% having clinical manifestations of diabetic neuropathy associated. In 2017, a total of 448 patients were hospitalized for complications of diabetes. We performed a retrospective analysis of 150 consecutive patients who underwent surgery for neuropathic diabetic foot lesions.

Results: The analyzed patients had a favorable postoperative progression, benefiting from distal perfusion. Ray resection was the preferred surgical intervention. Major amputation was performed in $10 \%$ of cases with extensive gangrene and sepsis, amputation of the calf being preferred in all situations.

Conclusions: The management of these patients is delicate, often multidisciplinary approach being necessary. A well-managed therapeutic attitude can make the difference between preserving or losing the pelvic limb.
\end{abstract}

Key words: neuropathy, diabetes, ulceration, Charcot

\section{Introduction}

The prevalence of diabetes in Romania is one of the largest in Europe, given that it is considered that for each newly diagnosed diabetic patient, there are 1-2 undiagnosed cases (1). Diabetes determines vascular and nerve damage, with disease progression as a result of cardiovascular, renal and ocular damage, as well as the occurrence of diabetic foot lesions. The diabetic foot is a complex entity that occurs as a result of the association of several ethiopathogenic factors. Arterio-pathy, neuropathy and infection, which are associated with foot injury, deformities, skin mycoses, limitations of joint mobility, or deficiencies in the healthcare system are at high risk for complications that may ultimately lead to lower limb amputations. Complications of the diabetic foot are a major problem of the public health system in terms of costs and the need for social assistance, especially in cases where surgery is represented by amputation, minor or major (2). Preventing and treating injuries can reduce the number of amputations by more than $80 \%$ (3). Diabetic neuropathy can be defined as a neurological, clinical or subclinical disorder that occurs in patients with diabetes in the absence of other causes of neuropathy and which manifests itself in the somatic or vegetative component of the nervous system. Recognition of this pathology as a consequence of diabetes is attributed to Marchal Calvi (1864), but the first mention dates back to 1778 (4). In 1998, a definition was drafted, that can be used in a simple way in medical practice: "diabetic neuropathy is defined by the presence of symptoms and/or signs of dysfunction in the 
peripheral nerves in people with diabetes, after exclusion of other causes" (5). Early recognition of neuropathy in patients with diabetes is useful because many patients are asymptomatic, while others may experience non-diabetic neuro-pathies. There is an impact on quality of life, autonomic neuropathy associated with increased morbidity and mortality, but available treatments can be effective. Various studies have shown that diabetic neuropathy involves diffuse impairment of all nerve structures, with alteration of large myelin fibres skeletal muscles, vibratory sensitivity, proprioceptive and tactile, as well as amyelinic or weakly myelinated fibres, autonomous, painful and thermal sensitivity. Peripheral neuropathy correlates with age, duration of diabetes, glycaemic control, presence of cardiovascular disease, smoking, HDL cholesterol, diastolic TA, microalbuminuria. Thus, the prevalence of polyneuropathy in the diabetic population is approximately 6 times higher than in nondiabetic patients and in its occurrence it is important to know the number of years from onset of the disease (onset - 6-8\%, 10 years $20 \%$ at 25 years $-50 \%)$. It has also been shown that the prevalence of symptoms is higher in men than in women. The first symptoms that occur in somatic polyneuropathy are: pain, paraesthesia, cramps, tingling, muscle asthenia, later on skin hyperesthesia, cold hypersensitivity, muscle atrophy, paresis or absence of ROT (6). The most significant complications of the diabetic foot are ulcerations and amputations at the lower extremities, which are responsible for the substantial use of health care resources, in addition to the morbidity and mortality they bring to diabetic patients. Leg ulcers are wounds associated with difficult healing, which occur in the patho-physiological changes induced by diabetes, anatomical deformities of the diabetic foot and environmental factors, with several etiological factors. The correct treatment of ulcers is the main method of prophylaxis of amputations. Once ulceration is detected, it is essential to recognize the contribution of each of the major prognostic factors, i.e. neuropathy, ischemia and infection. Depending on the pre- dominant component, ulcerations are classified into neuropathic and ischemic.

\section{Material and Method}

In the Surgery Department of I. Cantacuzino Clinical Hospital, a significant number of patients with diabetic foot lesions are admitted and treated annually, approximately $40 \%$ of whom have associated with obvious clinical manifestations of diabetic neuropathy. In 2017, out of a total of 448 patients hospitalized for complications of diabetes, 182 also had a diagnosis of diabetic neuropathy. We performed a retrospective analysis of 150 consecutive patients who underwent surgery for diabetic foot lesions specific for the predominance of diabetic neuropathy. The objectives of the study are are to establish appropriate surgical indication and to analyse postoperative results in order to reduce the number of severe, potentially debilitating lesions and the number of major amputations.

Men's predominance of 4/1 was observed, similar to the data found in the literature. Persons in their 60s and 70s were more common among the patients analysed.

Although patients experienced a long-term development of diabetes, there were 6 cases of newly discovered diabetes at the time of admission for foot injury. Of the 150 patients analysed, 89 patients were treated with oral antidiabetic agents, while 48 patients were insulin-treated. In 6 patients, diabetes was diagnosed after hospitalization and 7 patients were on diets as the only treatment method for diabetes (Fig. 1).

With regard to type of diabetes, only 12 patients, representing $8 \%$, had type I diabetes, the rest of analysed patients had type II diabetes.

Even though clinical examination at admission showed present distal pulses (dorsalis pedis and/or posterior tibial artery), a vascular surgery consult was performed, our surgery department having a vascular surgeon integrated. Simple neuropathic ulceration is a superficial lesion, usually located on the plantar face of the toes, which is interested in 


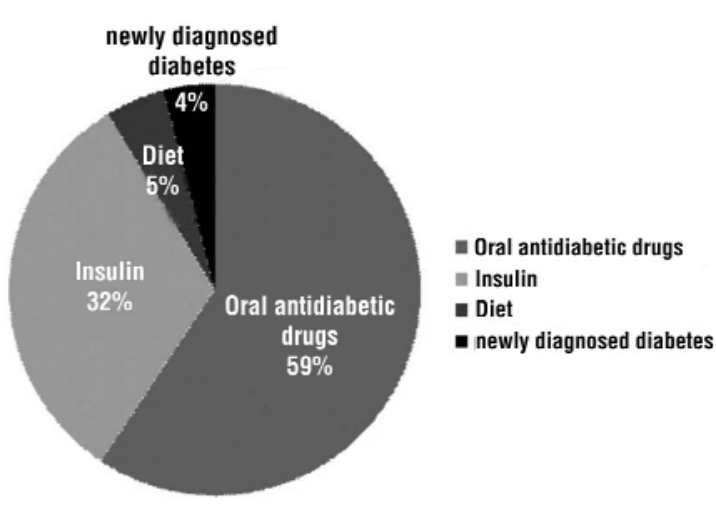

Figure 1. Treatment of diabetes at the time of admission

the entire thickness of the skin. Although early and appropriate treatment consisting of debridement of hyperkeratosis zones, application of local antiseptics and pressure discharge results in healing, most often the absence of algic syndrome leads to therapeutic neglect and progression of lesions to more advanced stages. Deep neuropathic ulceration is firm, with elevated hyperkeratosis edges. In depth, it is covered with detritus and secretions, exceeding the thickness of the skin to the ligament plane or even the bone. It does not heal spontaneously, it tends to become chronic and is usually superinfected with germs from the surface of the skin, gram-positive (streptococci, staphylococci). Appropriate treatment consists in associating antibiotic therapy, debriding and resting in orthopaedic facilities. In the present study, simple and profound ulcerations, without bone contact were reported in 39 cases, representing $26 \%$ of the studied group.

In 85 cases, the anatomical clinical form encountered was neuropathic ulceration with osteitis or superinfected osteoarthritis, highlighting the lack of medical education of the diabetic patients, the little use of prophylaxis methods due to the absence of podiatric physicians in our medical system. Deep ulceration with osteitis or superinfected osteoarthritis represents the late and complicated stage of the deep ulcer in which the infectious process concerns the underlying bone or metatarsalphalange joint, in some cases patients presenting with disintegrated osteo-articular fragments due to the suppurative process. Bone destruction is rapidly diagnosed with a simple foot radiography, which is why this investigation is necessary for all patients with diabetic foot. Rapid surgical treatment is required in these situations. Neglecting the evolution of the infectious process and the presence of an aggressive polymorphic flora can lead to aggressive forms of cellulite and fasciitis in the forefoot, evolving to extensive gangrene. Neuropathic gangrene with extensive lesions, associating sepsis and metabolic dysfunctions, occurred in 18 patients, respectively $12 \%$. 8 cases showed a clinical form of Charcot neuroarthropathy at the time of admission (Fig. 2).

In 39 cases with simple or deep neuropathic ulceration, periodic excisional debridement and recommendation of orthopedic footwear for pressure relief of the ulceration were chosen. The technique of excisional debridement involves the removal of all devitalized and necrotic areas until apparently bloody and healthy tissues remain.

Toe amputation or ray resection was the preferred surgical intervention, being found in half of the patients studied. In selected cases of patients with incipient osteoarthritis, initially, conservative treatment was tempered by the combination of a good bone penetration antibiotic, such as Clindamycin, and the application of topical antiseptic dressings after local excisional debridement (Figs. 3, 4).

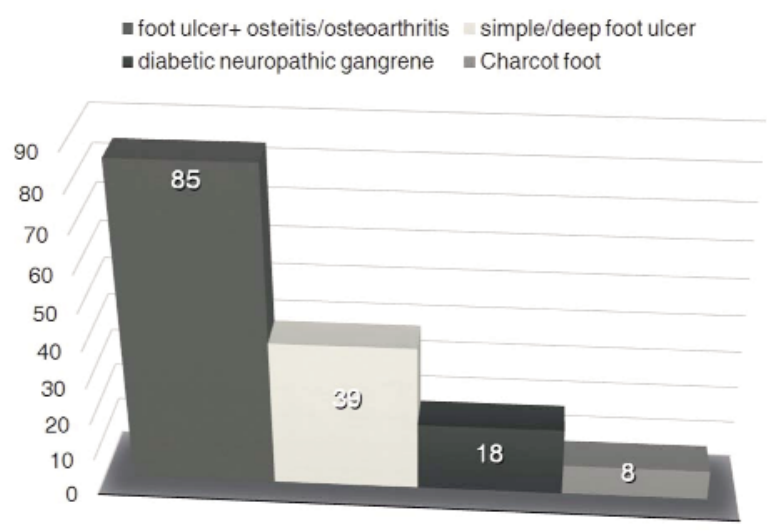

Figure 2. Anatomical clinical forms at patient intake 


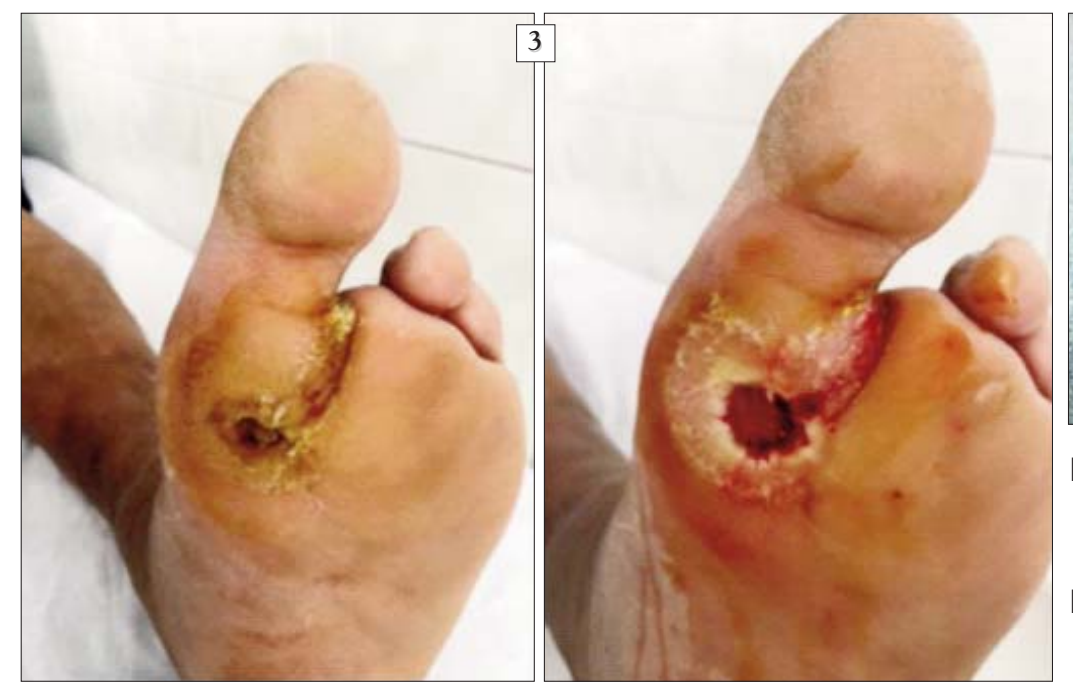

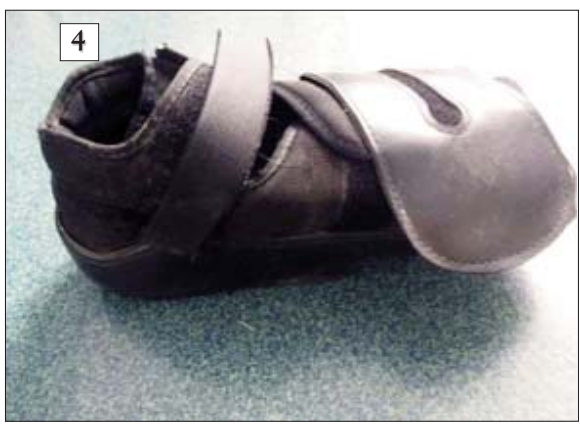

Figure 3. Plantar ulceration corresponding to MTF I, before and after excisional debridement

Figure 4. Orthopaedic footwear for pressure relief in the MTF joints
From the total of 85 patients with neuropathic ulceration with osteitis or superinfected osteoarthritis, 76 cases were surgically treated by performing ray resections. The technique of ray resection presumes the removal of the toe, the metatarso-phalangeal joint and the metatarsal head. We prefer to just partially suture the remaining wound.

In 4 selected cases, patients with ulceration and lesions of osteitis or osteoarthritis, even with superinfection and added limited necrosis, located in the phalanges, a trans-phalangeal, distal or proximal amputation was preferred. The remaining wound after the removal of the distructed phalanx and the subjacent interphalangeal joint was in all cases primary sutured.

In 5 cases of plantar ulcers corresponding to the metatarsophalangeal joints, resection of the joint and the head of the metatarsal was chosen, with the preservation of the finger. The skin incision was made on the dorsum of the foot overlying the osteomyelitic metatarsus and MTP joint. We opt for a dorsal approach as it involves healthy soft tissues free from inflammation, and this area is not on any pressure points on the foot. The infected bones and all septic tissue are excised and carefully debrided; then the wound is washed, and the skin closed with interrupted sutures. In patients with neuropathic gangrene with extensive plantar or dorsal suppurative dissemination, extensive incisions and counter incisions were performed, extensive excisional debridement associated or not with ray resections, the presence of distal perfusion resulting in a long evolution in the production of granulated wounds. Transmetatarsal amputation was the surgical option for 3 patients in our group. If more than three toes or metatarso-phalangeal joints were compromised at admission, an initial transmetatarsal amputation was preferred as primary surgical management in 2 patients of the analyzed lot. Otherwise, the transmetarsal amputation was reserved for one case primary treated with limited surgical intervention, with less than three ray resections, that were insufficient to control the local sepsis process.

In cases of severe sepsis and metabolic dysfunction, in patients with extensive suppurative dissemination, sometimes at the calf, the indication was of major amputation. Invariably, in all 15 such situations, representing $10 \%$ of the analysed lot, amputation was chosen. Distal perfusion, found in all 15 patients by the presence of pulse in the popliteal artery, as well as the definite advantages in terms of prosthesis, were the primary arguments in support of surgical indication (Fig. 5).

Although the exact ethiopathogenicity of Charcot's disease is unclear, it appears to the community after a 10-12 year history of diabetes, under low glycaemic control conditions. The current consensus admits that osteoarthropathy appears secondary to both repeated 


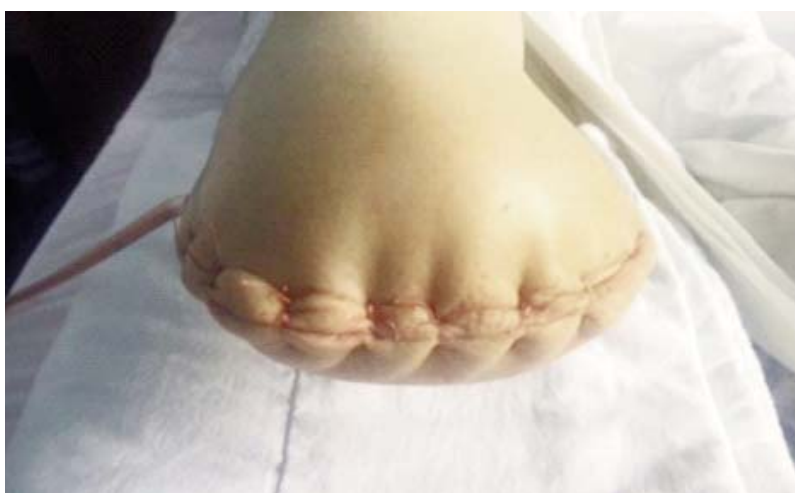

Figure 5. Amputation blunt in a patient with neuropathic gangrene, the first postoperative day

micro-trauma and as a hindrance to hyperaemia from autonomic neuropathy, knowing that these patients have a peripheral pulse present. Thus both theories, neurotraumatic and neurovascular are accepted (7-9). In the 8 cases of Charcot neuroarthropathy, patients experienced acute stages of plantar ulceration and suppurative phenomena in the foot, requiring surgical procedures - excisional debriding and/or corrective osteotomies. They later received a recommendation for orthosis and/or orthopaedic examination to assess the possibility of foot remodelling surgery.

The treatment is multimodal and aims to achieve plant stability, solve soft tissue problems and prevent acute episodes, osteitis and osteoarthritis and ulceration, thus avoiding amputations. The gold standard of the Charcot's foot treatment is gypsum or customized orthopaedic immobilization in order to reduce deformations and predominantly discharge the prominent areas. Immobilization can be maintained for up to 1 year depending on the evolutionary particularities of each patient. Surgical treatment is used in case of failure of conservative treatment in less than $25 \%$ of cases. Corrective osteotomies can be performed to prevent plantar ulceration, corrective fusions, screw osteo-synthesis or external fixators. Although these patients have distal perfusion in case of severe septic complications, the surgery solution can be a major amputation (10).

\section{Results}

The analysed patients underwent a favourable postoperative progression, the distal perfusion being the determining factor for obtaining wound healing. The periods of hospitalization varied between 1 and 14 days, with an average duration of 5 days. All patients received empirical antibiotherapy with third generation cephalosporins, subsequently being treated with an effective antibiotic on germs isolated from wound secretion.

The short term postoperative outcome was favorable in all cases analyzed. However, considering the long term outcome we found out that 27 patients, representing 18\% were readmitted in less than 1 year for lesions in the same leg or in the contralateral leg, emphasizing the lack of compliance with medical recommendations at discharge, especially regarding off-loading therapy.

To illustrate the importance of differentiating the neuropathic gangrene from the ischemic one and the favourable net prognosis following a well-managed therapeutic strategy, we present the case of patient G.D., admitted and treated in the surgery department of the Dr. I Cantacuzino Clinical Hospital. This is a patient known with type II diabetes and diabetic neuropathy for 13 years, treated with insulin and Milgamma. At the time of admission there is significant swelling in the right leg, accompanied by inflammatory phenomena and febrile syndrome, local pain and areas of necrosis in the dorsal face of the foot, the clinical aspect being diabetic gangrene. Laboratory analyses show important leucocytosis, moderate anaemia and increases in urea and creatinine (WBC:

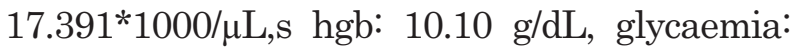
$313.03 \mathrm{mg} / \mathrm{dL}$, ureea: $105.64 \mathrm{mg} / \mathrm{dL}$, creatinine: $1.29 \mathrm{mg} / \mathrm{dL})$ (Fig. 6).

In the figure, it can be noticed that postamputation of V-finger is not cured, there being an ulceration at this level. Paraclinical investigations confirm the presence of peripheral diabetic neuropathy by performing specific sensitivity tests, the ankle-brachial index is 0.9 , and the foot radiography describes a metatarsal V-line with osteolysis (Fig. 7). 


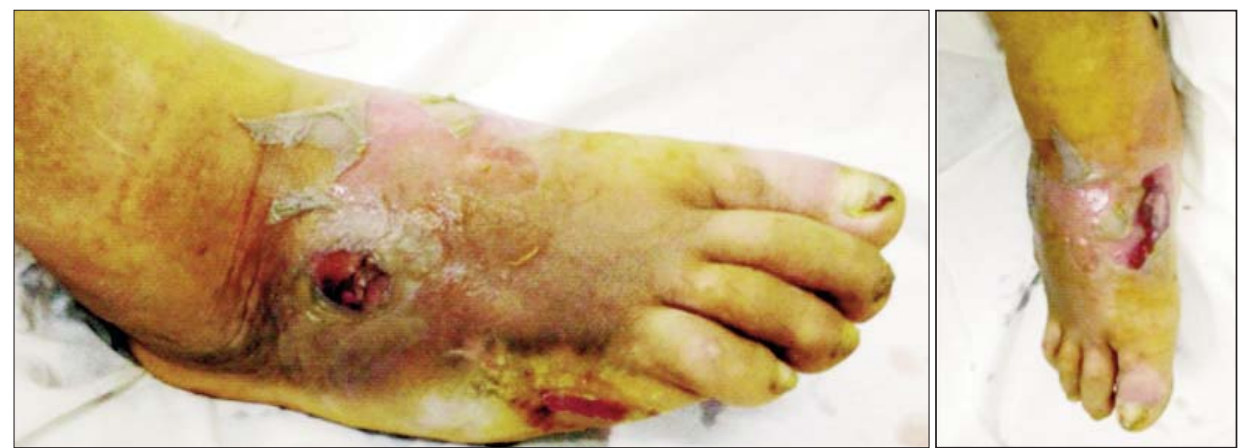

Figure 6. Neuropathic diabetic gangrene
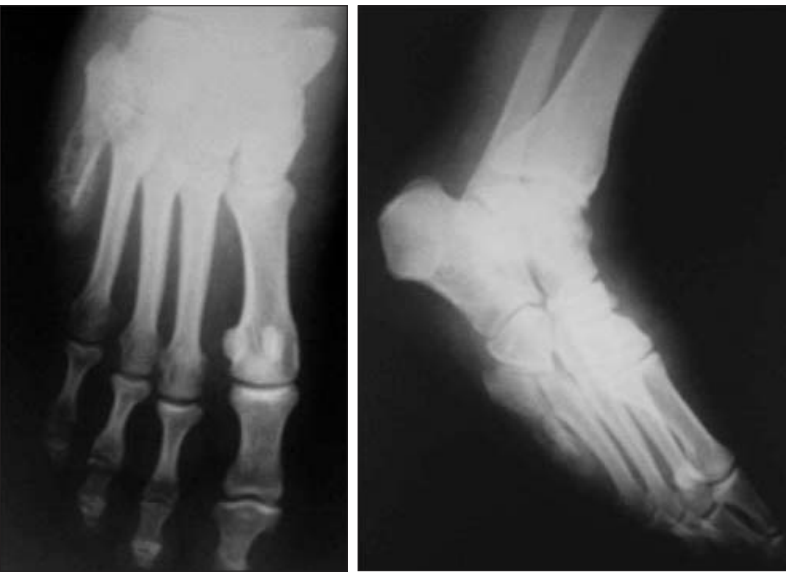

Figure 7. Front and radius foot radiographs with metatarsal V osteolysis areas

Surgical treatment consisted of incisions and contraindications, aggressive excisional debridement with tarso-metatarsal joint exposure, and resection of the osteitis metatarsal blunt. Antibiotherapy with generic III cephalosporin was instituted and a sample was taken for bacteriological and antibiogram examination. The immediate surgical appearance with areas of plaque flare ischemia and suppurative fusions imposed a new excisional debridement on postoperative day 4 (Figs. 8, 9).

The bacteriological exam isolated Staphylococcus aureus MRSA. The empirical treatment with generic cephalasporin III being resistant was replaced with a combination of vancomycin-clindamycin, antibiotics susceptible to antibiogram. During hospitalization, after the therapeutic adjustment of the insulin regimen, control of glycaemic values (Figs. 10, 11).

The complex therapeutic approach has benefited in addition to local surgical interventions, and to local topical dressing applications with Ag. Negative pressure therapy was considered inappropriate due to tarsometatarsal osteo-articular exposure. After obtaining a fully granulated wound, a free-cut skin diversion will be performed. As an evolu-

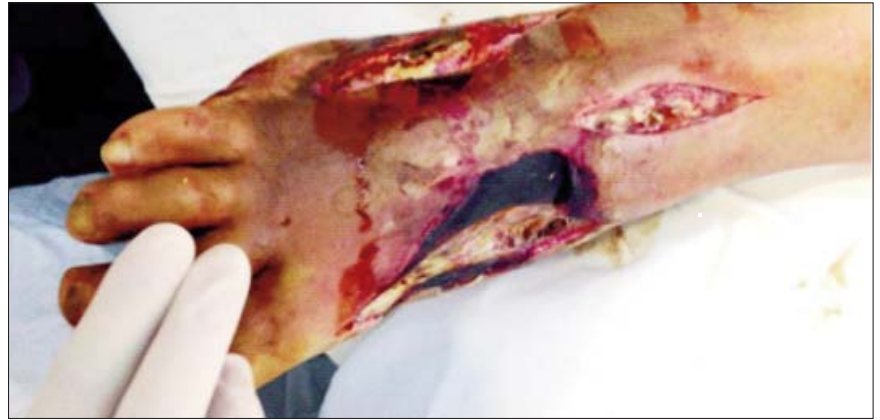

Figure 8. Immediate postoperative appearance

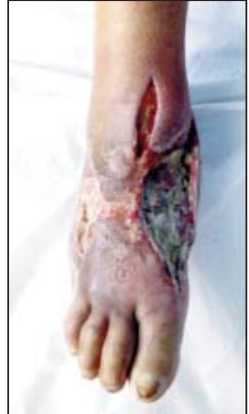

Figure 9. Postoperative appearance after the second intervention 


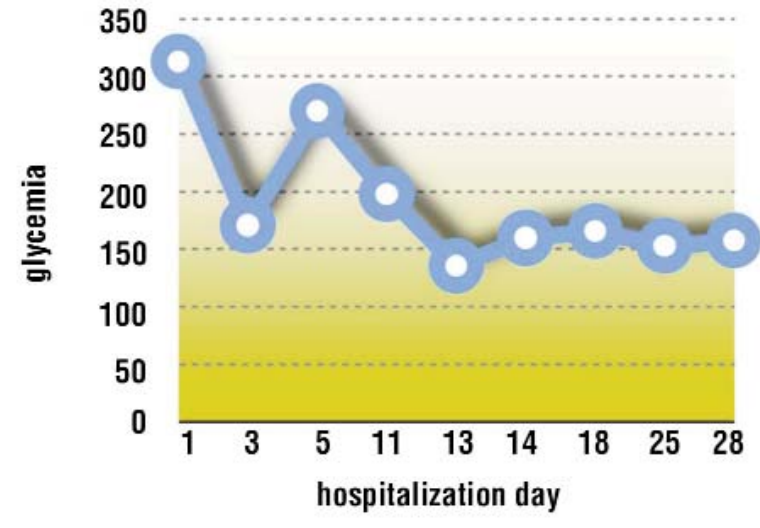

Figure 10. The glycaemic rate curve for the period of hospitalisation

tionary potential, the patient could develop a Charcot foot, which is why he received the recommendation to wear specialized orthopaedic footwear.

\section{Discussions}

Treatment of the neuropathic diabetic foot should include 3 steps: prophylaxis, treatment of risk factors for complications and surgical treatment of acute, lesional and infectious complications. Prophylaxis includes the medical education of diabetic patients who need to be aware of the importance of the disease and the risk of complications. With regard to the treatment of risk factors, pathogenic therapy for diabetic neuropathy is quite limited, with long-term treatments having questionable results. In addition to treating algic neuropathic symptoms with tricyclic, antiarrhythmic and anticonvulsant antidepressants, neurolysis of the posterior tibial nerve was also proposed. Foot biomechanical disorders can be corrected by tailored customized orthotics based on plant stress recording.

The curative step of treating acute, lesional and infectious complications of the neuropathic diabetic foot is in fact the surgical stage of the treatment. The acute nature of the lesions requires early initiation of an initial, empirical, wide-spectrum antibiotic treatment to be re-evaluated after obtaining the result of the antibiogram. For soft tissue infections, the preferred antibiotic is last generation cephalosporin or ertapenem. If the septic process localizes at the osteoarthritic level, superior results were observed after the administration of Lincomycin, Clindamycin and Rifampicin, antibiotics with good bone penetration. Surgical intervention has the role of septic healing, pus evacuation and devitalization tissue removal. Debridement can be surgically

Figure 11. Appearance at discharge and one month after surgery
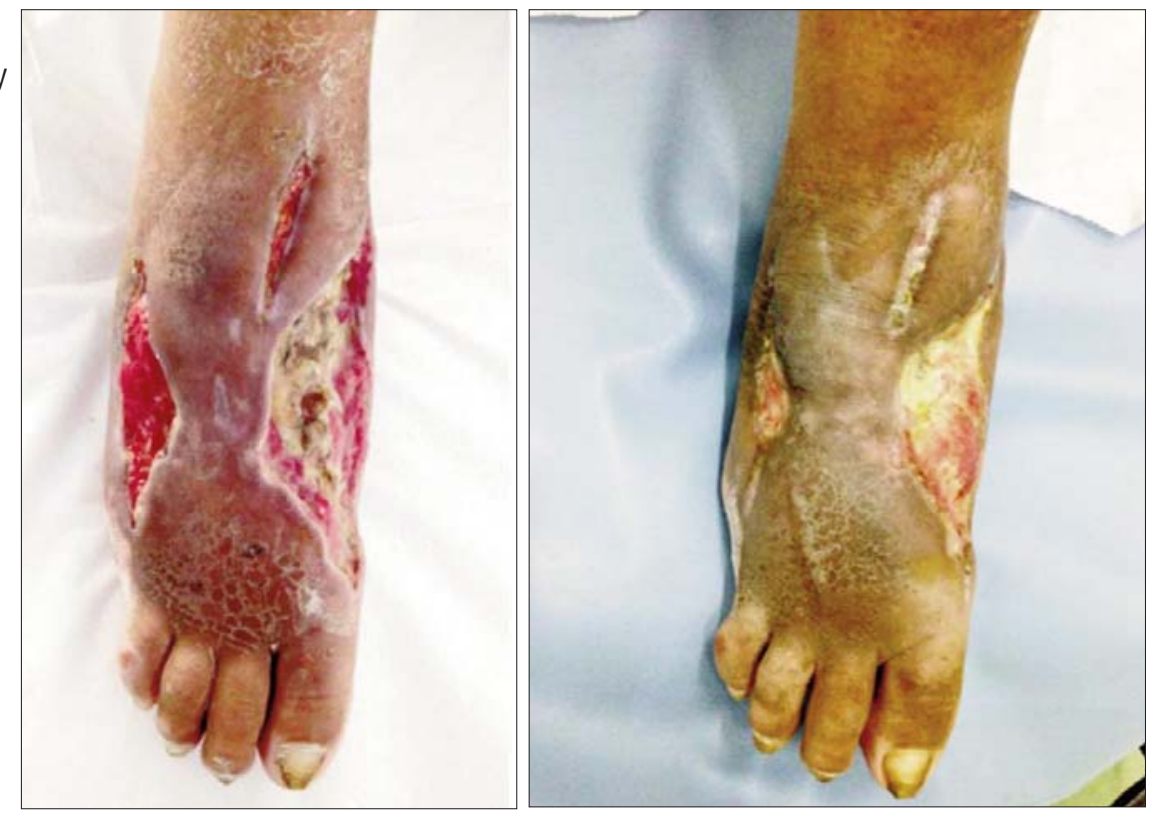
done, enzymatically, by last generation wet dressings, mechanically by means of a saline jet or biological by sterile larvae. Favouring granulation and the healing process can be achieved by negative pressure therapy. The resulting skin defects can be covered with free-cut skin diversions, collaboration with a plastic surgeon being recommended. In case of bone skeleton interest, minor amputations, which preserve the ankle joint, are recommended. This category includes trans-phalangeal amputation, ray resection, trans-metatarsal and trans-tarsal amputations. Neuropathic diabetic ulcers are the result of joint deformation and corresponding high pressure points. We encounter them more often at the level of the MTF I or plantar joint at the ends of the other metatarsal heads. Under conditions of preserved blood circulation, the pressure-discharge and treatment of the infection ensure healing $(11,12)$. In relation to clinical experience, we found a very low compliance among patients with individualized orthopaedic load-relieving shoes. Each year, 2\% of all diabetic patients will develop a leg ulcer, while $15 \%$ will develop ulceration throughout their lives $(13,14)$. Leg ulceration precedes $85 \%$ of amputations, the causal relationship between them being evident. It is alarming that $15 \%$ of all ulcerations will ultimately require amputation at a certain level $(15,16)$.

The excision of the MTF joint and the head of the metatarsal is an alternative to ray resection for patients with neuropathic diabetic plantar ulcers. This technique provides rapid healing without the sacrifice of healthy tissue, along with a superior cosmetic result (17). In our study it was reported in 5 selected cases. We consider this operation useful in neuropathic diabetic foot ulcers over the MTP joint, where the blood supply is good, and only for selected patients where losing a toe is a major psihological and/or cosmetic issue. The diabetic neuropathy foot complications can very easily mislead to disproportionate surgical indications, and to a large number of pelvic limb major amputations. For a better use of the surgical management arsenal, in our departament was imagined and conceived a therapeutic-prognostic index to help the surgeon establish an adequate procedure $(18,19)$. As an alternative to surgical management for chronic neuropathic nonifected diabetic ulcers, negative pressure wound therapy did not prove its effectiveness over standard therapy, hight rates of recurrence being reported (20). In diabetic foot ulcers patients, the risk of limb amputation depends on severity of infection at the initial presentation, previous history of lower extremity amputation, peripheral arterial disease and presence of any walking disability. Prevention of future amputations in these patients rely on early identification and management by a multidisciplinary team (21).

\section{Conclusions}

Diabetic neuropathy is the most common and early chronic complication of diabetes. The diagnosis is delayed, usually after the appearance of the leg ulcer.

As demonstrated above our recommendation is to perform excisional debridement associated afterwards with off-loading therapy for simple and deep ulcers without bone contact. In cases with neuropathic ulceration with osteitis or superinfected osteoarthritis the surgical recommendation is to perform ray resections, transphalangeal amputations being reserved for lesions limited to the distal phalanx. In selected compliant patients a resection of the joint and metatarsal head can be perfomed for esthetic purpose, the toe being preserved. If more than three toes or metatarso-phalangeal joints are compromised at admission we suggest to perform a primary transmetarsal amputation. Forneuropathic gangrene with extensive plantar or dorsal suppurative dissemination we recommend extensive incisions and counter incisions, extensive excisional debridement associated or not with ray resections if metatarso-phalangeal joints are compromised. In cases of severe sepsis and metabolic dysfunction, in patients with extensive suppurative dissemination we suggest to perform a major amputation. For patients with Charcot neuroarthropathy excisional debriding and/or corrective osteotomies must be followed byrecommendation for ortho- 
sis and/or orthopaedic examination.

A multidisciplinary team approach (general surgeon, orthopedist, plastic surgeon, podiatrist) is essential for good results and good longterm prognosis. Even though an adequate surgical management provides good postoperative results as shown, after healing is obtained, special personalized footwear is mandatory to prevent recurrence. The role of the podiatric physician is both to prevent appearance of tisular lesions and to prevent recurrence after efficient surgical management by prescribing the accurate measures, especially off-loading therapy. Diagnosis and early treatment of diabetic neuropathy can lead to a conservative surgical attitude, a significantly reduced number of major amputations and low overall costs in the public health system.

\section{Ethical Standards}

Human rights: All the procedures used were in line with the ethical standards described in the 1964 Helsinki Declaration and subsequent amendments

\section{Conflict of Interests}

All authors state that there are no conflicts of interest

\section{Informed Consent}

It was obtained from all patients included in the study

\section{References}

1. Mota M, Popa SG, Mota E, Mitrea A, Catrinoiu D, Cheta DM, et al. Prevalence of diabetes mellitus and prediabetes in the adult Romanian population: PREDATORR study. J Diabetes. 2016;8(3): 336-44. Epub 2015 May 6.

2. Sanders LJ. Diabetes mellitus: prevention of amputation. J Am
Podiatr Med Assoc. 1994;84(7):322-28.

3. Campo Guinea N, Portillo MC. Patients self-management of type 2 diabetes: a narrative review Campo Guinea N, An. Sist. Sanit. Navar. 2013;36(3):489-50.

4. Boulton A. Neuropatiadiabetica in practicaclinica. Ed. Farma Media; 2012. p 23-29.

5. Boulton AJM, Gries FA, Jervell JA. Guidelines for the diagnosis and outpatient management of diabetic peripheral neuropathy. Diabet Med. 1998; 15. p. 508-514.

6. Rubba P. Diabetes Mellitus and Localiations of Obliterating Arterial Disease of the Lower Limbs-Angiology,1991;42(4):296-301

7. Delano PJ. The pathogenesis of Charcot's joint. AJR 1946;(56)2: 189-200

8. Edmonds ME, Roberts VC, Watkins PJ. Blood flow in the diabetic neuropathic foot Diabetologia 1982;22:9-15.

9. Edelman SV, Kosofsky EM, Paul RA. Neuro-osteoarthropathy (Charcot's joint) in diabetes mellitus following revascularization surgery: three case reports and a review of the literature. Arch Int Med 1987;147:1504-1508

10. Wagner FW. The diabetic foot. Orthopedics 1997;10:163-72.

11. Grimm A, Kastenbauer T, Sauseng S, Sokol G, Irsigler K. Progression and distribution of plantar pressure in Type 2 diabetic patients. Diabetes NutrMetab. 2004;17:108-13.

12. Boulton AJ. Pressure and the diabetic foot: clinical science and off-loading techniques. Am J Surg. 2004;187(Suppl):17S-24S.

13. Ramsey SD, Newton K, Blough D. Incidence, outcomes, and cost of foot ulcers in patients with diabetes. Diabetes Care 1999;22: 382-387.

14. Palumbo PJ, Melton LJ. Peripheral vascular disease and diabetes, in Diabetes in America (Harris MI, Hamman RF, eds.), Govt. Printing Office, Washington, DC, US, 1985, pp. XV1- XV21.

15. Reiber GE, Boyko E, Smith DG. Lower extremity ulcers and amputations in individuals with diabetes, in Diabetes in America (Boyko EJ, Reiber GE, Bennett PH, eds.), Govt. Printing Office, Washington, DC, US, 1995, pp. 409-427.

16. Pecoraro RE, Reiber GE, Burgess EM. Pathways to diabetic limb amputation: basis for prevention. Diabetes Care 1990;13:513-521.

17. YC Chan, JP Morales, and KG Burnand. Excision of Metatarsal Bone and Metatarso-Phalangeal (MTP) Joint in Neuropathic Diabetic Foot Ulcer. Annals of The Royal College of Surgeons of England;2007;89(4): 431-432.

18. Bobirca F, Mihalache 0 , Georgescu D, Patrascu T. The New Prognostic - Therapeutic Index for Diabetic Foot Surgery Extended Analysis. Chirurgia (Bucur). 2016;111(2):151-5.

19. Bobirca F, Catrina E, Mihalache O, Georgescu D, Patrascu T. The new prognostic-therapeutic index - an easy method of establishing surgical indication in the pathology of the diabetic foot.J Med Life. 2014; 7(Spec Iss 3): 13-19.

20. Borys S, Hohendorff J, Koblik T, Witek P, Ludwig-Slomczynska AH, Frankfurter $C$ et al. Negative-pressure wound therapy for management of chronic neuropathic noninfected diabetic foot ulcerations - short-term efficacy and long-term outcomes. Endocrine (2018 Aug 11). Available from https://doi.org/10.1007/ s12020-018-1707-0

21. Ferreira L, Carvalho A, Carvalho R.Short-term predictors of amputation in patients with diabetic foot ulcers. Diabetes Metab Syndr. 2018;12(6):875-879. 